\title{
Diagnosis of human herpesvirus 6B primary infection by polymerase chain reaction in young children with exanthematic disease
}

\author{
Diagnóstico de infecção primária pelo herpesvírus humano tipo 6B através da técnica de \\ reação em cadeia da polimerase em crianças com doença exantemática
}

\author{
Ivna de Melo Magalhães ${ }^{1}$, Rebeca Vasquez Novo Martins ${ }^{1}$, Renata Oliveira Vianna ${ }^{2}$, Solange Artimos Oliveira ${ }^{2}$ \\ and Silvia Maria Baeta Cavalcanti ${ }^{1}$
}

\begin{abstract}
Introduction: Exanthem subitum is a classical rash disease of early childhood caused by human herpesvirus 6B (HHV-6B). However, the rash is frequently misdiagnosed as that of either measles or rubella. Methods: In this study, a nested multiplex polymerase chain reaction (PCR) was used to diagnose HHV-6B primary infection, differentiate it from infections caused by HHV-6A and compare it to antibody avidity tests. The samples were separated into case group and control group according to the results of the indirect immunofluorescence assay (IFA) technique. Results: From the saliva samples analyzed, HHV-6A DNA was detected in $3.2 \%$ of the case group and in $2.6 \%$ of the control group. Regarding HHV-6B, PCR detected viral DNA in $4.8 \%$ of the case group and in $1.3 \%$ of the control group. Among the serum samples studied, a frequency of $1.7 \%$ was determined for HHV-6A in the case group and $1.2 \%$ in the control group. PCR did not detect HHV-6B DNA in serum samples. The sensitivity and specificity of the PCR technique ranged from $0 \%$ to $4.8 \%$ and $97.5 \%$ to $100 \%$, respectively, compared to IFA. Conclusions: The PCR technique was not suitable for diagnosing primary infection by HHV-6B in children with exanthematic disease and should not substitute the IFA.

Keywords: Human herpesvirus 6. Exanthem subitum. Multiplex PCR. Indirect immunofluorescence assay. Primary infection.
\end{abstract}

\section{RESUMO}

Introdução: $\mathrm{O}$ exantema súbito é uma doença comum durante a infância e pode ser causada pela infecção por herpesvirus humano tipo 6B (HHV-6B). No entanto, a erupção cutânea característica dessa doença, é frequentemente confundida com outras viroses como sarampo ou rubéola. Métodos: Foi utilizada a técnica de reação em cadeia da polimerase (PCR) no formato nested multiplex para o diagnóstico de infecção primária por HHV-6B, diferenciação entre as infecções causadas pelo HHV-6A e comparação com testes de avidez de anticorpos. As amostras foram separadas em grupo caso e grupo controle, de acordo com os resultados do teste de imunofluorescência indireta (IFA). Resultados: Nas amostras de saliva analisadas, o DNA do HHV-6A foi detectado em 3,2\% no grupo caso e em 2,6\% das amostras do grupo controle. Em relação ao HHV-6B, o DNA viral foi observado em 4,8\% no grupo caso e em 1,3\% no grupo controle. Após a realização da PCR nas amostras de soro, o DNA do HHV-6A foi detectado em $1,7 \%$ no grupo caso e em $1,2 \%$ no grupo controle, enquanto o DNA do HHV-6B não foi detectado. A sensibilidade e a especificidade da técnica de PCR variaram de $0 \%$ a $4,8 \%$ e de $97,5 \%$ a 100\%, respectivamente, quando comparado com a IFA. Conclusões: A técnica de PCR não se mostrou adequada para o diagnóstico de infecção primária pelo HHV-6B em crianças com doença exantemática e não deve substituir a IFA.

Palavras-chaves: Herpesvírus humano tipo 6. Exantema súbito. Multiplex PCR. Imunofluorescência indireta. Infecção primária.

1. Laboratório de Diagnóstico Virológico, Departamento de Microbiologia e Parasitologia, Instituto Biomédico, Universidade Federal Fluminense, Niterói, RJ. 2. Departamento de Doenças Infecciosas e Parasitárias, Hospital Universitário Antônio Pedro, Universidade Federal Fluminense, Niterói, RJ.

Address to: Dra. Silvia Maria Baeta Cavalcanti. Dept ${ }^{\circ}$ de Microbiologia e Parasitologia/Instituto Biomédico/UFF. Rua Professor Ernani Melo 101, Laboratório 321, 24210-130 Niterói, RJ, Brasil.

Phone: $55212629-2431$

e-mail: silviacavalcanti@vm.uff.br

Received in 08/11/2010

Accepted in 02/12/2010

\section{INTRODUCTION}

Exanthem subitum, or roseola infantum, is a classical rash disease of early childhood in which a high fever with very abrupt onset occurs that lasts 3 to 4 days, and a maculopapular rash which appears as the child's temperature falls following the crisis $^{1,2}$. In 1988, Yamanishi et $\mathrm{al}^{3}$ identified human herpesvirus 6 as a causal agent for this disease. Later, two genetically similar variants A and B were described. HHV-6A has not yet been firmly associated with any disease. Primary infection with HHV-6B, although usually asymptomatic, has been conclusively related to exanthem subitum ${ }^{4}$. However, despite a well defined syndrome, many years ago, it was observed that the rash is frequently misdiagnosed as that of either measles or rubella ${ }^{5}$. Any study of the etiology of rashes misdiagnosed clinically as measles or rubella must therefore include diagnostic methods able to distinguish between HHV$6 \mathrm{~B}$ and other viral agents of exanthematic syndromes.

The indirect immunofluorescence assay (IFA) for the detection of low avidity IgG antibody in a single convalescent serum sample is accepted as the gold standard. This test differentiates primary from long-standing infection. Nevertheless, some reports show cross-reactivity between HHV-6 and HHV7; moreover, this technique does not differentiate between HHV-6 variants ${ }^{4}$.

Multiplex polymerase chain reaction (PCR) assays provide a cost-effective approach for detection of the presence of more than one virus in a single reaction ${ }^{6}$. In this study, a technique of nested multiplex PCR was used to diagnose and differentiate infections caused by HHV-6A, HHV-6B ${ }^{7}$ and evaluate its usefulness in the diagnosis of HHV-6 primary infection in children compared to antibody avidity tests.

\section{METHODS}

This study was conducted between January 1998 and December 2006 at a general hospital and a large primary health care unit in Niterói, State of 
Rio de Janeiro, Brazil. A total of 125 serum samples and 138 saliva samples were obtained from children younger than four years of age presenting a rash with: (1) recent primary infection, defined by low antibody avidity detected by IFA (case group), and (2) past primary infection, determined by high antibody avidity detected by IFA (control group), as described by Vianna et $\mathrm{al}^{8}$. All the samples had previously tested negative for measles, rubella, dengue fever and parvovirus B19 infections ${ }^{8}$.

DNA was extracted from $200 \mu \mathrm{l}$ of whole saliva and serum using the QIAmp kit (QIAgen, Germany). Ten microliters were used for the qualitative nested PCR multiplex assay using the HHV-6 A and B primers described previously ${ }^{9}$. Briefly, amplification was performed in $50 \mu \mathrm{l}$ of reaction mixture (1X PCR buffer, $200 \mu \mathrm{M}$ dNTPs, $1.5 \mathrm{mM}$ $\mathrm{MgCl}_{2}, 50 \mathrm{pmol}$ of each primer, $0.25 \mathrm{U}$ unit of Taq polymerase platinum, and $10 \mu \mathrm{l}$ of sample). The mixture was submitted to 30 amplification cycles of denaturing at $90^{\circ} \mathrm{C}$ for $1 \mathrm{~min}$, annealing at $62^{\circ} \mathrm{C}$ for $2 \mathrm{~min}$ and extension at $72^{\circ} \mathrm{C}$ for $3 \mathrm{~min}$. After the first round, $2 \mu \mathrm{l}$ of the amplicon was used as template for the second round of PCR under the same conditions, except for the inner primers used. Polymerase chain reaction products were analyzed on $1.5 \%$ agarose gel with ethidium bromide staining for visualization of DNA under ultraviolet light. HHV-6A generated 195bp fragments and HHV-6B $423 \mathrm{bp}$. The technique presented a sensibility of 100 copies $/ 50 \mu \mathrm{L}$ for HHV-6A and 10 copies/50 $\mu \mathrm{L}$ for HHV-6B ${ }^{7}$.

A data bank was generated and analyzed using EPInfo 2004 statistical software package (Center for Disease Control and Prevention, Atlanta, EUA, 2004). Prevalence rates were compared by the Chi square test with Yates' correction. The significance level of tests ( $p)$ was set at 0.05 .

\section{Ethics considerations}

Free, informed consent was obtained from the parents or guardians of the patients. The study protocol was approved by the Hospital's research ethics committee (CEP CMM/HUAP no. 85/02).

\section{RESULTS}

From the saliva samples analyzed, HHV-6A DNA was detected in $3.2 \%$ of the case group and in $2.6 \%$ of the control group (Table 1). Regarding HHV-6B, PCR detected viral DNA in $4.8 \%$ of the case group and in $1.3 \%$ of the control group (Table 2). Among the serum samples studied, a frequency of $1.7 \%$ was determined for HHV-6A

TABLE 1 - Comparative analysis between indirect immunofluorescence assay and the multiplex PCR for the detection of HHV-6A in saliva samples.

\begin{tabular}{lccc} 
& \multicolumn{2}{c}{ Indirect immunofluorescence assay } & \\
\cline { 2 - 4 } PCR & $\begin{array}{c}\text { low avidity IgG } \\
\text { (case group) }\end{array}$ & $\begin{array}{c}\text { high avidity IgG } \\
\text { (control group) }\end{array}$ & Total \\
\hline DNA positive & 2 & 2 & 4 \\
\hline DNA negative & 60 & 79 & 139 \\
\hline Total & $\mathbf{6 2}$ & $\mathbf{8 1}$ & $\mathbf{1 4 3}$ \\
\hline
\end{tabular}

HHV-6B: human herpesvirus 6B, PCR: polymerase chain reaction, sensitivity: $3.2 \%$ (95\% CI 0.6-12.2\%), specificity: $97.5 \%$ (95\% CI 90-99.5\%), Kappa value 0.56.

in the case group and $1.2 \%$ in the control group (Table 3). PCR did not detect HHV-6B DNA in serum samples (Table 4). Based upon the above results, the sensitivity and specificity of the PCR technique were calculated and compared to avidity of IgG (IFI) for the detection of HHV-6A and HHV-6B DNA, as presented in Tables
TABLE 2 - Comparative analysis between indirect immunofluorescence assay and the multiplex PCR for the detection of HHV-6B in saliva samples.

\begin{tabular}{lccc} 
& \multicolumn{2}{c}{ Indirect immunofluorescence assay } & \\
\cline { 2 - 4 } PCR & $\begin{array}{c}\text { low avidity IgG } \\
\text { (case group) }\end{array}$ & $\begin{array}{c}\text { high avidity IgG } \\
\text { (control group) }\end{array}$ & Total \\
\hline DNA positive & 3 & 1 & 4 \\
\hline DNA negative & 59 & 75 & 134 \\
\hline Total & $\mathbf{6 2}$ & $\mathbf{7 6}$ & $\mathbf{1 3 8}$
\end{tabular}

HHV-6B: human herpesvirus 6B, PCR: polymerase chain reaction, sensitivity: $4.8 \%$ (95\%CI 1.5-14.4\%), specificity: 98.7\% (95\%CI 91.9-99.9\%), Kappa value 0.56.

TABLE 3 - Comparative analysis between indirect immunofluorescence assay (IFA) and the multiplex PCR for the detection of HHV-6A in serum samples.

\begin{tabular}{lccc}
\hline & \multicolumn{2}{c}{ Indirect immunofluorescence assay } & \\
\cline { 2 - 4 } PCR & $\begin{array}{c}\text { low avidity IgG } \\
\text { (case group) }\end{array}$ & $\begin{array}{c}\text { high avidity IgG } \\
\text { (control group) }\end{array}$ & Total \\
\hline DNA positive & 1 & 1 & 2 \\
\hline DNA negative & 56 & 67 & 123 \\
\hline Total & $\mathbf{5 7}$ & $\mathbf{6 8}$ & $\mathbf{1 2 5}$ \\
\hline
\end{tabular}

HHV-6B: human herpesvirus 6B, PCR: polymerase chain reaction, sensitivity $1.8 \%$ (95\% CI 0.1-10.6\%), specificity: 98.5\% (95\% CI 91-99.9\%), Kappa value 0.54 .

TABLE 4 - Comparative analysis between indirect immunofluorescence assay and the multiplex PCR for the detection of HHV-6B in serum samples.

\begin{tabular}{lccc}
\hline & \multicolumn{2}{c}{ Indirect immunofluorescence assay } & \\
\cline { 2 - 4 } PCR & $\begin{array}{c}\text { low avidity IgG } \\
\text { (case group) }\end{array}$ & $\begin{array}{c}\text { high avidity IgG } \\
\text { (control group) }\end{array}$ & Total \\
\hline DNA positive & 0 & 0 & 0 \\
\hline DNA negative & 57 & 68 & 125 \\
\hline Total & $\mathbf{5 7}$ & $\mathbf{6 8}$ & $\mathbf{1 2 5}$ \\
\hline
\end{tabular}

HHV-6B: human herpesvirus 6B, PCR: polymerase chain reaction, sensitivity: $0 \%$, specificity: $100 \%$, Kappa value 0.54 .

1 to 4 . Due to the low sensitivity and high specificity obtained, Kappa values provided intermediate results, showing moderate agreement rates ranging from 0.54 for serum samples to 0.56 for saliva samples.

\section{DISCUSSION}

A molecular assay was performed to detect HHV-6 primary infection in samples from children presenting rash with recent primary infection or past primary infection. Although some studies have proposed that the presence of HHV-6 DNA in serum or plasma alone was a definitive marker of active viral replication ${ }^{10,11}$, the present results do not support these suggestions. The frequency of HHV-6A and HHV-6B was much lower than other studies ${ }^{6,12}$, which did not separately report the prevalence of both variants (A and B). This observation led us to argue whether the detection of HHV-6 was partially related to variant $A$, which can be occasionally detected in human body fluids, despite not being correlated with any disease $\mathrm{e}^{4}$. Moreover, recent studies have shown that high levels of viral DNA in blood and sera could be related to HHV-6 chromosomal integration ${ }^{13}$.

In the 1990s, several authors proposed that following the primary infection, HHV-6 is shed in saliva chronically or intermittently, in disagreement with the present results that indicated low levels of HHV-6 in the saliva studied ${ }^{14-16}$. These low rates of detection lead our group to verify the sensitivity and specificity parameters, in 
order to compare the PCR performed here to the gold-standard diagnosis assay available: the immunofluorescence assay. As shown in Tables 1 to 4, sensitivity rates were very low compared to IFI, suggesting a high prevalence of false-negative results achieved by PCR. Regarding specificity, concordant results were obtained for negative samples by both methodologies. Hence, Kappa values showed moderate agreement rates ( 0.54 to 0.56 , Tables $\mathbf{1}$ to $\mathbf{4}$ ), which is attributed to the high specificity rates. Since positive samples showing antibody response by IFA were negative by PCR, the use of PCR as a diagnostic tool for HHV-6 infection cannot validated by this study.

It is important to note that the present samples were tested for different agents and manipulation could lead to DNA degradation that would determine lower detection rates for PCR. However, the current data are in agreement with that described by Suga et $\mathrm{al}^{17}$, who reported that viremia decreases rapidly after rash onset, an event related to the induction of specific immunity to the virus. Therefore, molecular diagnosis of HHV-6 primary infection is useful before seroconversion ${ }^{18}$. Studies from Zerr et al ${ }^{19}$ associated the detection of viral DNA with febrile episodes, which would suggest PCR as an early diagnostic procedure, specially for the first week of symptoms.

In summary, the PCR technique is not adequate for diagnosing primary infection by HHV-6B in young children with exanthematic disease and is not a viable substitute for the indirect immunofluorescence assay when diagnosing HHV-6 primary infection. Further studies are required to evaluate new possible methods to identify HHV-6B and differentiate active infection associated with this virus from other agents that cause rashes.

\section{CONFLICT OF INTEREST}

The authors declare that there is no conflict of interest.

\section{FINANCIAL SUPPORT}

This research was supported by the Coordenação de Aperfeiçoamento de Pessoal de Nível Superior (CAPES/Brazil) and the Pro-Reitoria de Pesquisa, Pós-Graduação e Inovação da UFF (PROPPI/UFF).

\section{REFERENCES}

1. Oliveira SA, Turner DJ, Knowles W, Nascimento JP, Brown DW, Ward KN. Primary human herpesvirus- 6 and -7 infections, often coinciding, misdiagnosed as measles in children from a tropical region of Brazil. Epidemiol Infect 2003; 131:873-879.

2. Hall CB, Caserta MT, Schnabel KC, Boettrich C, Mcdermott MP, Lofthus GK, et al. Congenital infections with human herpesvirus 6 (HHV6) and human herpesvirus 7 (HHV7). J Pediatr 2004; 145:472-477.

3. Yamanishi K, Okuno T, Shiraki K, Takahashi M, Kondo T, Asano Y, et al. Identification of human herpesvirus- 6 as a causal agent for exanthem subitum. Lancet 1998; I:1065-1067.

4. Ward KN. The natural history and laboratory diagnosis of human herpesviruses-6 and -7 infection in the immunocompetent. J Clin Virol 2005; 32:183-193.

5. Tait DR, Ward KN, Brown DWG, Miller E. Exanthem subitum (roseola infantum) misdiagnosed as measles or rubella. BMJ 1996; 312:101-102.

6. Kidd IM, Clark DA, Bremner JA, Pillay D, Griffiths PD, Emery VC. A multiplex PCR assay for the simultaneous detection of human herpesvirus 6 and human herpesvirus 7, with typing of HHV-6 by enzyme cleavage of PCR products. J Virol Methods 1998; 70:29-36.
7. Yamamura AMY, Cavalcanti SMB, Knowles WA, Freire MS, Nascimento JP. Human herpesvirus- 6 and -7 detection by the Polymerase chain reaction and isolation of HHV-7 from saliva. Jornada Científica do Instituto Oswaldo Cruz. Mem Inst Oswaldo Cruz 2001; 1 (suppl):4.

8. Vianna RAO, Oliveira SA, Camacho LAB, Knowles W, Brown D, Pereira ACM, et al. Role of human herpesvirus 6 infection in young Brazilian children with rash illnesses. Pediatr Infect Dis J 2008; 27:533-537.

9. Yalcin S, Karpuzoglu T, Suleymanlar G, Mutlu G, Mukai T, Yamamoto T, et al Human herpesvirus 6 and human herpesvirus 7 infections in renal transplant recipients and healthy adults in Turkey. Arch Virol 1994; 136:183-190.

10. Huang LM, Kuo PF, Lee CY, Chen JY, Liu MY, Yang CS. Detection of human herpesvirus-6 DNA by polymerase chain reaction in serum or plasma. J Med Virol 1992; 38:7-10.

11. Secchiero P, Zella D, Crowley RW, Gallo RC, Lusso P. Quantitative PCR for human herpesviruses 6 and 7. J Clin Microbiol 1995; 33:2124-2130.

12. Tanaka-Taya K, Kondo T, Mukai T, Miyoshi H, Yamamoto Y, Okada S, et al. Seroepidemiological study of human herpesvirus- 6 and -7 in children of different ages and detection of these two viruses in throat swabs by polymerase chain reaction. J Med Virol 1996; 48:88-94.

13. Ward KN, Leong HN, Nacheva EP, Howard J, Atkinson CE, Davies NWS, et al. Human herpesvirus 6 chromosomal integration in immunocompetent patients results in high levels of viral DNA in blood, sera, and hair follicles. J Clin Microbiol 2006; 44:1571-1574

14. Jarrett RF, Clark DA, Josephs SF, Onions DE. Detection of human herpesvirus-6 DNA in peripheral blood and saliva. J Med Virol 1990; 32:73-76.

15. Kido S, Kondo K, Kondo T, Morishima T, Takahashi M, Yamanishi K. Detection of human herpesvirus 6 DNA in throat swabs by polymerase chain reaction. J Med Virol 1990; 32:139-142.

16. Hall CB, Caserta MT, Schnabel KC, Long C, Epstein LG, Insel RA, et al. Persistence of human herpesvirus 6 according to site and variant: possible greater neurotropism of variant A. Clin Infect Dis 1998; 26:32-137.

17. Suga S, Yoshikawa T, Kajita Y, Ozaki T, Asano Y. Prospective study of persistence and excretion of human herpesvirus- 6 in patients with exanthem subitum and their parents. Pediatrics 1998; 102:900-904.

18. Caserta MT, Hall CB, Schnabel K, Lofthus G, Marino A, Shelley L, et al. Diagnostic assays for active infection with human herpesvirus 6 (HHV-6). J Clin Virol 2010; 48:55-57.

19. Zerr DM, Meier AS, Selke SS, Frenkel LM, Huang ML, Wald A, et al A population-based study of primary human herpesvirus 6 infection. N Engl J Med 2005; 352:768-776. 